\title{
Editorial
}

\section{RIO QUE CRUZA, RIO QUE DESCE: LUTA E PERMANÊNCIA NO ARAGUAIA- XINGU}

\section{Samira dos Santos Ramos e Célia Ferreira de Sousa}

"Nossas vidas são os rios.
Minha vida é este Araguaia!
Indescritivel,
indecifrável.
Que se ama e se agradece, e se teme e se deseja;
ao qual se volta sempre,
como a um lar, fatídico e feliz"

Pedro Casaldáliga

A Revista Alembra (RA) é um periódico de publicação online e gratuita do Instituto Federal de Educação, Ciência e Tecnologia do Estado de Mato Grosso, Campus Confresa. Promove a difusão de produção científica das grandes áreas de Letras e Humanidades contemplando Linguística, Literatura, Ciências Humanas e áreas afins, com foco às questões teóricas e críticas pertinentes aos estudos de diversidade e espacialidades, difundindo também a produção científica da região Araguaia-Xingu e desconstruindo discursos de esquecimento e apagamento cultural.

A Revista Alembra, em seu trabalho de divulgação científica, expande o diálogo entre a região e as suas múltiplas fronteiras: o local e o universal convergem nas águas dos rios. Pensamos o Araguaia-Xingu para o mundo e pensamos o mundo do Araguaia-Xingu.

O dossiê do segundo número da Revista AlembrA, Palavra, Educação e Sustentabilidade na Região Araguaia-Xingu, é composto por artigos que propõem discutir a região que congrega uma fronteira agrícola, o maior assentamento rural da América Latina, a maior quantidade de denúncias de trabalho análogo à escravidão, amplos territórios indígenas, um dos portais da Amazônia, dois dos principais rios brasileiros e fronteira com a maior ilha genuinamente fluvial do mundo, a Ilha do Bananal, que pode ser acessada a pé da cidade de Santa Terezinha nas épocas de seca. Esta diversidade de processos humanos sobre os recursos naturais e territórios coexiste entre tensões políticas, sociais e culturais que marcam a região.

A Educação manteve estreita relação com os movimentos sociais e esteve engajada na década de 1970 na luta de ribeirinhos, camponeses e indígenas por permanência na terra e 
resistência ao latifúndio, registrando na cultura da população que o conhecimento e o direito estão intrinsicamente ligados. Atualmente, o DNA com que nasceu marca a verticalização do ensino. A educação básica e superior em uma região de vastos municípios ligados por centenas quilômetros de estradas de terra, é território de luta por acesso, qualidade e permanência, discutida em eventos como o "Roda de Diálogos sobre Educação no Araguaia: Educação do Campo, Escolar Indígena, Quilombola e de Jovens e Adultos em foco", com última edição organizada pela Universidade Federal de Mato Grosso, e participação articulada em fóruns municipais e regionais para eleger representantes para o Fórum Permanente de Debates da Educação de Jovens e Adultos de Mato Grosso, este interinstitucional.

A Revista AlembrA, ao divulgar as pesquisas realizadas sobre o Araguaia-Xingu ou $a$ partir dele em seus primeiros dois números, marca seu lugar de fala e une a voz do Araguaia às pesquisas de excelência produzidas por todo o Brasil após a democratização do Ensino Superior.

No artigo Araguaia-Xingu: reflexões aos desafios sobre o desenvolvimento sustentável regional, de Iberê Martí Moreira da Silva, através da coleta de dados secundários do Instituto Brasileiro de Geografia e Estatística e revisão da literatura, realiza uma análise histórica do Norte do Araguaia, caracterizando a ocupação do território e compondo o panorama histórico, ambiental, social e econômico da população. O artigo colabora com apontamentos e possíveis estratégias para o desenvolvimento sustentável.

Também abordando a agricultura e desenvolvimento da região, ainda que em outra perspectiva, o artigo Perspectivas de futuro dos jovens estudantes do assentamento São José: frente ao fenômeno de envelhecimento da população rural, de Alessandra Caroline Ghiorzi, Eleandra Negri Costa, Maria do Rosário Soares Lima e Rosaline Araújo de Morais Piastrelli, aborda a fundamental discussão sobre os caminhos da agricultura familiar frente ao êxodo de jovens, tendo como locus o assentamento São José, no município de Vila Rica - MT. O estudo colabora com a compreensão das variáveis que afetam a juventude campesina e pensa as políticas públicas existentes e necessárias para uma perspectiva de permanência.

Em Políticas de formação continuada de professores da Educação Básica, em Mato Grosso, a partir dos anos de 1990, de Haroldo Borges, Heloisa Salles Gentil e Neures Batista de Paula Soares, o locus estende-se, a partir da região Norte Araguaia, para as políticas educacionais do Estado de Mato Grosso, discutindo as colaborações do Projeto Sala do Educador para o desenvolvimento da autonomia na atuação dos professores das escolas estaduais na elaboração de estratégias e práticas de ensino nos contextos específicos de suas comunidades escolares. 
O artigo A busca do eu a partir do outro: considerações acerca da identidade africana no conto "As mãos dos pretos" de Bernardo Honwana, de Celiomar Porfírio Ramos e Marly Augusta Lopes de Magalhães, com aporte teórico na área de Literatura e Sociedade, discorre sobre a identidade negra a partir do conto do autor moçambicano.

E o artigo convidado, Entre o lago e a história: Pedro Casaldáliga e a consciência da missão, é uma contribuição de Michael Jhonatan Sousa Santos à Revista AlembrA. O autor, com pesquisa em andamento na Universidade Federal de Mato Grosso, tem como corpora os poemas de Pedro Casaldáliga e analisa a representação do espaço natural na poesia. Agora, através da análise literária da obra de Pedro, voltamos ao contraste entre colonização marcada pela opressão social e a exuberância da natureza presente na região do Araguaia-Xingu, aqui nomeada como nordeste de Mato Grosso.

Desejamos a todos uma proveitosa leitura! 